cost of fuel has risen by 55 per cent, but the price per unit has risen by only 26 per cent. It is expected that the reduction in oil-firing will rosult in an increase in the consumption of coal by about $2 \cdot 5-3$ million tons a year in the 1960 's. Mr. Maudling did not think that there should then be an embarrassing surplus of small coal, but other uses of small coal are being investigatod. As regards capital investment, the present rising level of investment in electricity will continue but at a lower rate than previously planned. In the nuclear power programme, the development of Bradwell, Berkeley, Hinckley Point and Hunterston will proceed as planned, but there will be some delay in starting the later stations in the programme and the net, effect will be to delay the completion of the full programme by one year. In repeating the assurances previously given in the White Paper and elsewhere that the accident at Windscale could not occur in the power stations being built for the Central Electricity Authority, Mr. Maudling emphasized that this applies equally to the power stations which the industry is offering for sale abroad. $\mathrm{He}$ added that a reactor safoty committee has beon established on which Lloyd's and the British insurance industry are represented, and a formal safety code for the design and operation of nuclear power stations is being prepared. As regards the siting of nuclear power stations, Mr. Maudling argued that there is neither the time nor the trained staff for a complete survey of the United Kingdom before decisions are taken, but he did not mect the objection that such a survey is only demanded when ti is proposed to invade national parks or like areas.

Brussels Universal and International Exhibition, 1958

Work on the 500-acre site for the Brussels Universal Exhibition continues apace, and the majority of the structures are ahead of schedule. Most of the buildings have taken their final shape, and work is now in progress on interiors and exhibits. About 8,000 men are at present working on the site. Two of the nine spheres of the 'Atomium' have been completed, and three others have their main structure in position. Work has begun on the topmost sphere, and the lift mechanism has been installed in the central column.

Details are also available of some of the plans for the International Hall of Science, sponsored by fifteen nations. All the exhibits are to be of a collective and non-national character. 'The hall will have four sections: The Atom; The Crystal; The Molecule; The Living Cell. The Atom Section will include displays of radioactive elements, nuclear and thermonuclear reactions and solar energy. There will be models of accelerators from the European Nuclear Energy Centre at Geneva, a demonstration of the direct use of solar energy in a furnace, and a fully operating experimental reactor. The Crystal Section will contain, among other things, a model of a crystal $13 \mathrm{ft}$. $\times 13 \mathrm{ft}$, containing 800 lights showing the basic elements of the crystal. The Molecule Section will explain analytical, synthetic and physical chemistry. Its main feature will be a model of 2 crystallized virus. The Living Cell Section will allow the public to see, by means of a prototype colour-television set, essential cell activities otherwise only visible by microscope. 'There will also be illustrations dealing with chromosomes, heredity, blood groups, cell division, and photosynthesis.

\section{Nordic Institute for Theoretical Atomic Physics}

THE five Nordic countries (Denmark, Finland, Iceland, Norway and Sweden) have set up a joint organization, under the chairmanship of Prof. Niels Bohr, for the purpose of strengthening scientific co-operation in the field of atomic physics. One of the main objects of the organization is the establishment of the Nordisk Institut for Teoretisk Atomfysik in Copenhagen in a building which will be erected by the Danish Government in connexion with the existing premises of the Institute for Theoretical Physics of the University of Copenhagen. Further activities envisaged are exchange of Nordic scientists, organization of symposia, and visits of scientists from other countries to Nordie physics institutions.

Resoarch work and oducational activities will be the task of the staff of the Nordic Institute. Facilities will be provided for a number of younger physicists from the member States to receive advanced training in the field of theoretical atomic physics. For the interim period, until a formal agreement has been established by the participating governments, C. Møller has been appointed director of the Institute (during his absence on a visit to the United States, T. Gustafison is acting as director), assisted by G. Källén, B. Mottelson and S. Rozental. On February 1 , L. Rosenfeld will join the permanent staff of the Institute.

\section{Journal of Mental Deficiency Research}

THE causation of mental disease of all types has tended to attract researoh workers perhaps less than in any other branch of medicine, and only the truly devoted have turned thoir onergios into trying to discover the causes of mental deficiency. At first sight the mental defective seems so hopeless, so finally damaged, that one feels despair. Nevertheless, research is worth while, and the realization that certain of the acute specific fevers can injure the foetus has aroused new hope. Those who work on these problems tend to be scattered in mental deficiency hospitals and work a great deal isolated from others engaged in similar activities. It is an excellent thing, and one which will be most welcome, to find that a journal has been founded to record their researches (Journal of Mental Deficiency Research, 1, No. 1 (July 1957). Pp. 65. Published half-yearly. Annual subscription rate: $15 s$. Single issues $7 s .6 d$. or 1.50 dollars. Publisbing manager: Mr. A. Highfield, 10 Shendon Way, Sevenoaks; 1957). The first number contains an excellent article by Penfield on "The Genetics of Anencephaly", a paper by Claridge and O'Connor on "The' Relationship between Incentive, Personality Type and Improvement in Performance of Imbeciles" and "A Survey of Mental Deficiency Types in the United States of America". A paper is contributed by Mittwoch on "Some Observations on the Leucocytes in Mongolism", and there is another article on phenylketonuria by Hsia, Paine and Driscoll. It is hoped that this valuable journal will have a long life and will bo able to maintain the high standard of its initial number. It is essential to all who are intorested in mental deficiency and will be consulted by anyone who hopes to further research.

\section{Annales de l'Institut Phytopathologique Benaki}

THERE is nothing in the first number of a new series of the Annales de l'Institut Phytopathologique Benaki (Nouvelle Série, 1, No. 1, 1957. Pp. 90. Kifissia-Athenes : Institut Phytopathologique Benaki, 